\title{
Captopril in heart failure secondary to a left to right shunt
}

\author{
N J SHAW, N WILSON, AND D F DICKINSON \\ Regional Paediatric Cardiology Unit, Killingbeck Hospital, Leeds
}

SUMmaRY Captopril was used in 20 infants aged less than 1 year with heart failure secondary to defects with predominantly a left to right shunt that was poorly controlled with digoxin and diuretics. Total daily dose of captopril ranged from 0.88 to $2.5 \mathrm{mg} / \mathrm{kg}$ (mean $1.3 \mathrm{mg} / \mathrm{kg}$ ) in three divided doses. Improvement in the control of heart failure was seen mainly as an increase in the rate of weight gain from a mean of $48 \mathrm{~g} /$ week before treatment to $102 \mathrm{~g} /$ week on treatment and a decrease in the mean respiratory rate from 68 breaths/minute to 60 breaths/minute. Side effects were seen in four patients-two with asymptomatic mild hypotension, one with renal insufficiency which improved with a reduction in dose, and one with severe oliguria progressing to renal failure. Significant changes in plasma electrolyte concentration did not occur except in the infant who developed acute renal failure.

After encouraging reports on the use of captopril, an angiotensin converting enzyme inhibitor, for the treatment of cardiac failure in adults in both clinical ${ }^{1}$ and haemodynamic studies ${ }^{2}$ we used this drug in a group of infants with refractory heart failure. All were infants with high pulmonary blood flow and pulmonary hypertension secondary to a congenital cardiac defect with a predominantly left to right shunt.

\section{Patients and methods}

Captopril was used in 20 such infants over a three year period from April 1984 to April 1987. Details of diagnosis are given in the table. All were in heart failure, which was not controlled adequately by maximum doses of diuretics and digoxin and all were failing to thrive despite calorie supplementation of their diet. In several cases nasogastric tube feeding was necessary. All were in hospital at the time of introducing captopril so that they could be observed closely for any adverse effects. Before starting captopril urea and electrolytes were checked and recordings made of weight and blood pressure.

The median age at introduction of captopril was 3 months (range 1 to 7 months) with a median weight of $3100 \mathrm{~g}$. The maximum dose of captopril used ranged from 0.88 to $2.5 \mathrm{mg} / \mathrm{kg} /$ day with a mean dose of $1.3 \mathrm{mg} / \mathrm{kg} /$ day. All the infants were being treated with frusemide (range 2.2 to $8.5 \mathrm{mg} / \mathrm{kg} /$ day) and spironolactone (range 1.5 to $10 \mathrm{mg} / \mathrm{kg} /$ day) and 12 were receiving digoxin in a maintenance dose of 10 $\mu \mathrm{g} / \mathrm{kg} / \mathrm{day}$.

Captopril was introduced in an initial dose of $0.25-0.5 \mathrm{mg} / \mathrm{kg} /$ day in three divided doses and blood pressure was checked every 15 minutes for the first few hours. If the blood pressure did not fall by more than $15 \mathrm{~mm} \mathrm{Hg}$ or below $60 \mathrm{~mm} \mathrm{Hg}$ systolic the dose was increased by increments of $0.5 \mathrm{mg} / \mathrm{kg} / \mathrm{day}$ over the course of several days until a satisfactory clinical response had been obtained or to a maximum of $4 \cdot 0$ $\mathrm{mg} / \mathrm{kg} /$ day. Repeat assessment of full blood count and urea and electrolytes was made at intervals during the dosage increment and subsequently after a few weeks on treatment.

CONTROL OF HEART FAILURE

The degree of control of heart failure was assessed by measurement of heart and respiration rate and the rate of weight gain before and after the introduction of captopril. Mean heart rate and respiratory rate were obtained retrospectively from the nursing charts for a period of three days before captopril and for a similar period after the maximum dose for each patient had been achieved. Weight gain was measured over a four week period before and after the introduction of captopril. The feeding pattern was assessed as being all nasogastric tube feeds, part nasogastric tube feeds or all oral feeding. 
Table Clinical details of infants studied, captopril dose, and weight gain

\begin{tabular}{|c|c|c|c|c|c|c|}
\hline \multirow[t]{2}{*}{$\begin{array}{l}\text { Patient } \\
\text { No }\end{array}$} & \multirow[t]{2}{*}{ Diagnosis } & \multirow{2}{*}{$\begin{array}{l}\text { Age at } \\
\text { start of } \\
\text { treatment } \\
\text { (months) }\end{array}$} & \multirow{2}{*}{$\begin{array}{l}\text { Maximum } \\
\text { captopril } \\
\text { dose } \\
(\mathrm{mg} / \mathrm{kg} / \text { day })\end{array}$} & \multicolumn{2}{|c|}{$\begin{array}{l}\text { Weight gain } \\
\text { (g/week) }\end{array}$} & \multirow{2}{*}{$\begin{array}{l}\text { Duration of } \\
\text { treatment } \\
\text { (months) }\end{array}$} \\
\hline & & & & Before & After & \\
\hline 1 & $\begin{array}{l}\text { Ventricular septal defect, patent } \\
\text { ductus arteriosus }\end{array}$ & 1 & 1.5 & 80 & 177 & 3 \\
\hline 2 & Ventricular septal defect & 2 & $1 \cdot 2$ & -50 & 185 & 4 \\
\hline 3 & Ventricular septal defect & 2 & $1 \cdot 0$ & 55 & - & 2 days \\
\hline 4 & Atrioventricular septal defect & 2 & $1 \cdot 2$ & 120 & 43 & 3 \\
\hline 5 & Ventricular septal defect & 2 & $1 \cdot 2$ & 15 & 128 & 3 \\
\hline 6 & Ventricular septal defect & 2 & $0 \cdot 88$ & 147 & 44 & 3 \\
\hline 7 & $\begin{array}{l}\text { Transposition of great arteries, } \\
\text { ventricular septal defect }\end{array}$ & 2 & 1.5 & 223 & 238 & 1 \\
\hline 8 & Ventricular septal defect & 2 & $1 \cdot 0$ & 13 & $\begin{array}{r}200 \\
60\end{array}$ & 2 \\
\hline 9 & Ventricular septal defect & 3 & $2 \cdot 0$ & -30 & 85 & 8 \\
\hline 10 & Ventricular septal defect & 3 & $1 \cdot 5$ & 115 & 188 & 2 \\
\hline 11 & Single ventricle & 3 & $1 \cdot 0$ & 93 & 93 & 3 \\
\hline 12 & $\begin{array}{l}\text { Transposition of great arteries, } \\
\text { ventricular septal defect }\end{array}$ & 3 & $1 \cdot 2$ & 64 & 92 & 1 \\
\hline 13 & Ventricular septal defect & 4 & $2 \cdot 5$ & -105 & 105 & 4 \\
\hline 14 & $\begin{array}{l}\text { Ventricular septal defect, double } \\
\text { outlet right ventricle }\end{array}$ & 4 & $1 \cdot 4$ & 40 & 105 & 1 \\
\hline 15 & Ventricular septal defect & 4 & $1 \cdot 4$ & 63 & -63 & 4 \\
\hline 16 & Ventricular septal defect & 4 & $1 \cdot 0$ & 36 & 117 & 3 \\
\hline 17 & Ventricular septal defect & 6 & $1 \cdot 1$ & 0 & 83 & 3 \\
\hline 18 & Ventricular septal defect & 7 & $1 \cdot 3$ & 17 & 138 & 3 \\
\hline 19 & Ventricular septal defect & 7 & $1 \cdot 1$ & 63 & 33 & 2 \\
\hline 20 & Ventricular septal defect & 7 & $1 \cdot 2$ & 0 & 83 & 3 \\
\hline
\end{tabular}

The infants did not routinely have radiographs taken during the period of observation unless there was a specific indication, and heart size on a chest radiograph could not therefore be used as an indicator of improvement. Similarly as all of these infants had apical mid diastolic murmurs from high pulmonary blood flow it was impossible to use the presence or absence of a third heart sound to assess the degree of heart failure.

Statistical analysis was performed using Student's $t$ test.

\section{Results}

After exclusion of the one patient in whom treatment was discontinued because of renal failure (see below) the mean rate of weight gain before treatment was $48 \mathrm{~g} /$ week compared with $102 \mathrm{~g} /$ week in the period after the maximum dose of captopril had been achieved $(p<0 \cdot 02)$. Six of the 19 infants showed no change in the rate of weight gain but in the remainder the change was clearly related to the introduction of the drug.

There was no significant difference in the mean (SD) heart rate before (140 (12) beats/minute) and after (135 (10) beats/minute) captopril. The mean respiratory rate on captopril (60 (9) breaths/ minute), however, was significantly slower than that recorded before the treatment was initiated (68 (11) breaths/minute $)(p<0 \cdot 05)$.

In retrospect it is difficult to make any quantitative assessment of the change in feeding pattern. At the time treatment with captopril was started 10 infants were feeding orally but were unable to manage an adequate intake within a reasonable time of less than 30 minutes. Seven of these infants were discharged gaining weight steadily and completing feeds within an acceptable time. Two infants admitted on nasogastric tube feeds were discharged on full oral feeding while the remaining seven changed from a pattern where they were virtually entirely tube fed to a pattern where a substantial proportion of their daily milk intake was taken orally.

Complications of treatment were seen in four patients. Two infants developed asymptomatic hypotension which responded to discontinuing the drug and restarting on a lower dose. One infant (patient 10) was very sensitive to increments in the dose of captopril developing renal insufficiency (urea $19 \mathrm{mmol} / \mathrm{l}$, creatinine $141 \mathrm{mmol} / \mathrm{l}$ ) on a dose of $2.2 \mathrm{mg} / \mathrm{kg} /$ day which improved when the dose was reduced to $1.5 \mathrm{mg} / \mathrm{kg} / \mathrm{day}$. Acute renal failure occurred in one infant (patient 3 ) within 24 hours of starting captopril but fortunately recovered completely on cessation of the drug.

Apart from the two who developed renal impair- 
ment on treatment there was no significant change in plasma urea, creatinine or electrolytes following treatment with captopril. No patient became neutropenic on treatment.

Treatment duration has ranged from one to eight months. Fourteen of these infants have undergone surgical treatment for their cardiac problem. Five, with isolated ventricular septal defects, continue on medical treatment and one died after surgery for an unrelated problem. The death of this last patient could not be associated with the use of captopril.

\section{Discussion}

Many patients with congenital heart problems require medical treatment for congestive cardiac failure. Digoxin and diuretics have been used for many years but recently the value of this treatment, particularly the use of digoxin, has been questioned. ${ }^{1}$ Alternative approaches with vasodilators or inotropic agents have not proved to be entirely satisfactory, ${ }^{1}$ but the introduction of angiotensin converting enzyme inhibitors appears to offer some hope of progress.

Captopril blocks the conversion of the inactive peptide angiotensin I to the active peptide angiotensin II with a resulting decrease in peripheral vascular resistance. ${ }^{3}$ The production of aldosterone stimulated by angiotensin II is inhibited with a consequent reduction in secondary hyperaldosteronism thereby minimising salt and water retention. As peripheral vasoconstriction $^{4}$ and hyperaldosteronism ${ }^{5}$ are important features in the pathogenesis of congestive cardiac failure, captopril would appear to be a rational choice of drug for its treatment. It has been used extensively in adults with congestive cardiac failure secondary to coronary artery disease, valvular heart disease, or cardiomyopathy with benefit ${ }^{2}$ but there have been few reports of its use in children other than in renal parenchymal hypertension where it has been shown to be a safe and effective drug.

These patients in whom we have used captopril have benefited from its use presumably as a consequence of a decrease in left to right shunting after a fall in peripheral vascular resistance. Objective confirmation that this improvement results from a relatively greater decrease in systemic resistance as compared with pulmonary resistance would require an invasive haemodynamic study that we did not consider to be justifiable.

The main objective indications of improvement in the control of cardiac failure have been better weight gain (in 13 infants out of 19) and decreased respiratory rate (in 12 out of 19). It is possible that with time those patients with ventricular septal defects would have improved because of a decrease in the size of the defect. It seems unlikely, however, that this would have occurred within the timescale of a few weeks. Better weight gain might have been a consequence of the hospital admission because of the skill and persistence of experienced nursing staff in feeding 'difficult' babies. Most patients, however, had been in hospital for some time before the introduction of captopril and the change in feeding and weight gain, when it occurred, was always clearly related to the timing of the introduction of the drug.

As captopril inhibits aldosterone production, potassium excretion on captopril treatment is reduced and concomitant treatment with a potassium sparing diuretic is normally contraindicated. It is of interest therefore that although all our patients were on spironolactone at the start of treatment and the dose remained unchanged after captopril was introduced, hyperkalaemia was not a problem except in the two patients who developed transient impairment of renal function. Others have noted improvement in three patients who were receiving digoxin, a loop diuretic, and an angiotensin converting enzyme inhibitor after the introduction of spironolactone. ${ }^{8}$ The contraindication to this combination is clearly not absolute and in some circumstances a beneficial effect may be seen.

The results of any retrospective assessment need to be viewed with caution. Nevertheless, our findings are essentially the same as those reported recently by Scammell et al in a similar study. ${ }^{9}$ We have been encouraged by the response of some patients to captopril and will continue to use it particularly in babies with a hypertensive left to right shunt. Patients who benefit usually do so on a low dose of the drug and currently the maximum dose we use is about $1.5 \mathrm{mg} / \mathrm{kg} /$ day. Ideally a double blind controlled trial is needed to prove the effectiveness of captopril in controlling heart failure in these circumstances but this poses many problems both practical and ethical. For example, a recent double blind trial of an alternative angiotensin converting enzyme inhibitor in adults was abandoned on ethical grounds as the patients receiving active treatment were doing so much better. ${ }^{10}$ The major practical problem is that of finding a satisfactory objective measurement of improvement. Cardiac failure is a useful clinical term but a wide variety of pathological processes are involved and there is no universally agreed measurement of severity. A functional classification such as that of the New York Heart Association is often used in adult practice but could hardly be applied to infants.

References
1 Lipkin DP, Poole-Wilson PA. Treatment of chronic heart
failure: a review of recent drug trials. Br Med $J$ 1985;291:993-6. 
2 Kramer BL. Massic BM. Topic N. Controlled trial of captopril in chronic heart failure: a rest and exercise haemodynamic study. Circulation 1983:67:807-15.

${ }^{3}$ Atkinson AB, Morton JJ, Brown JJ, et al. Captopril in clinical hypertension. Changes in components of renin-angiotensin system and in body composition in relation to fall in blood pressure with a note on measurement of angiotensin 11 during converting enzyme inhibition. Br Heart $J$ 1980;44:290-6.

+ Cohn JN, Vasodilator therapy for heart failure: the influence of impedance on left ventricular performance. Circulation 1973:48:5-8.

5 Davis JD, Urquhart J, Higgins JT, Rubin EC. Hartroft PM. Hypersecretion of aldosterone in dogs with a chronic aorticcaval fistula and high output heart failure. Circ Res 1964:14: 471-85.

- Clcland JGF, Dargie HJ, Modsundu GP et al. Captopril in heart failure. A double blind controlled trial. Br Heart J 1984;52: $530-5$.
7 Sinaiko AR, Mirkin BL, Hendrick DA, Green TP, O'Dea RF. Antihypertensive effect and elimination kinetics of captopril in hypertensive children with renal disease. J Pediatr 1983;103: 799-804.

${ }^{8}$ Ikram H, Webster MWI, Nichols MG, Lewis GRI, Richards AM, Crozier IG. Combined spironolactone and converting-enzyme inhibitor therapy for refractory heart failure. Aust NZ J Med 1986;16:61-3.

9 Scammell AM, Arnold R, Wilkinson JL. Captopril in the treatment of infant heart failure: a preliminary report. Int $J$ Cardiol 1987;16:295-301.

10 The CONSENSUS trial study group. Effects of enalapril on mortality in severe congestive heart failure. $N$ Engl $J$ Med 1987:316:1429-35.

Correspondence to $\mathrm{Dr} \mathrm{N}$ Wilson, Killingbeck Hospital, York Road, Leeds LS14 6UQ.

Accepted 10 December 1987 